\title{
Knowledge, Perceived Risk, and Preventive Behaviors amidst Covid-19 Pandemic among Dental Students in Malaysia
}

\author{
Azlini Ismail ${ }^{1}$, Nur Hanisah Ismail ${ }^{2}$, Nur Yasrin Maisarah Abu Kassim ${ }^{2}$, Widya Lestari ${ }^{1}$, \\ Ahmad Faisal Ismail ${ }^{3}$ (D) and Cortino Sukotjo ${ }^{4, *}$ \\ 1 Department of Fundamental Dental and Medical Sciences, Kulliyyah of Dentistry, International Islamic \\ University Malaysia, Pahang 25200, Malaysia; dr_azlini@iium.edu.my (A.I.); drwidya@iium.edu.my (W.L.) \\ 2 Kulliyyah of Dentistry, International Islamic University Malaysia, Pahang 25200, Malaysia; \\ nhanismail25@gmail.com (N.H.I.); yasrinmaisarah26@gmail.com (N.Y.M.A.K.) \\ 3 Department of Pediatric Dentistry and Dental Public Health, Kulliyyah of Dentistry, \\ International Islamic University Malaysia, Pahang 25200, Malaysia; drfaisal@iium.edu.my \\ 4 Department of Restorative Dentistry, College of Dentistry, University of Illinois at Chicago, \\ Chicago, IL 60612, USA \\ * Correspondence: csukotjo@uic.edu
}

Citation: Ismail, A.; Ismail, N.H.; Abu Kassim, N.Y.M.; Lestari, W.; Ismail, A.F.; Sukotjo, C. Knowledge, Perceived Risk, and Preventive Behaviors amidst Covid-19 Pandemic among Dental Students in Malaysia. Dent. J. 2021, 9, 151. https://doi.org/ $10.3390 /$ dj9120151

Academic Editor: Hans S. Malmstrom

Received: 15 November 2021

Accepted: 8 December 2021

Published: 14 December 2021

Publisher's Note: MDPI stays neutral with regard to jurisdictional claims in published maps and institutional affiliations.

Copyright: (c) 2021 by the authors. Licensee MDPI, Basel, Switzerland. This article is an open access article distributed under the terms and conditions of the Creative Commons Attribution (CC BY) license (https:/ / creativecommons.org/licenses/by/ $4.0 /)$
Abstract: Purpose: Coronavirus disease 19 (COVID-19) has affected dental education in Malaysia However, studies on dental students' knowledge, perception, and behaviors with regards to COVID19 are very limited. Thus, this study aims to determine the knowledge status, perceived risk, and preventive behaviors of dental students in Malaysia regarding COVID-19. Methods: A cross-sectional study was conducted among students from 13 dental schools across Malaysia using online questionnaires. Results: From 355 respondents, 93.5\% obtained a high score of knowledge of COVID-19. Female respondents scored higher than males in perceived risks and preventive behaviors. Chinese respondents scored highest in knowledge, while Malay respondents had the highest perceived risk score. The mean preventive behavior score did not vary across ethnicity. On-campus students scored higher in knowledge and perceived risk whereas off-campus students practiced more preventive behaviors. Clinical students' knowledge score was higher than preclinical students. Final year students scored higher in knowledge and perceived risk compared to their juniors. Conclusion: The majority of dental students have good knowledge and a high perceived risk of COVID-19, and they practiced most of the preventive behaviors. However, the latest information on this disease should be incorporated into dental schools' curriculums and updated periodically.

Keywords: COVID-19; dental education; dental student; knowledge; perceived risk; preventive behavior; Malaysia

\section{Introduction}

Coronavirus disease 19 (COVID-19) was initially identified during the pneumonia outbreak in Wuhan City, Hubei Province, China [1]. After the local spread, it became a global outbreak and was declared a pandemic on 11th March 2020 by the World Health Organization [2]. The first index case of COVID-19 in Malaysia was announced on 25th January 2021 [3]. On 18th March 2020, the Malaysia government had to employ a Movement Control Order as a restriction intervention to curb the uncontrolled situation. After the drastic measure, the COVID-19 situation in Malaysia was getting better, with the lowest record of only one import case on 1 July 2020. However, by 20 September 2020, Malaysia was in the midst of the third wave of infections, in which cases were spurting non-stop. As of 12 September 2021, 224.11 million cases were confirmed globally, with 4.6 million deaths, and in Malaysia, there were 1,975,074 confirmed cases, with more than 20,711 fatalities found across all states [4].

During this pandemic, not only was the public's health in danger, but Malaysia's economic sector, education system, and healthcare services, including dental institutions 
were majorly impacted [5]. Dental professionals are among the forefronts at risk because their working environment can potentially create a virus-laden aerosolized environment [6]. Plaque or calculus are the major sources of bacteria and virus in the oral fluids. These pathogens can be aerosolized during dental procedures that lead to airborne contamination thus transmitting airborne diseases including SARS-CoV-2 which has been detected in the saliva of infected individuals $[7,8]$. This has raised a high level of health risk perception among dental practitioners, including clinical staff, dental educators, and students regarding dental practice during the COVID-19 outbreak [9]. Because of this matter, some extra precautionary measures such as the usage of a higher level of personal protective equipment (PPE) has increased drastically during dental practice [9]. Besides that, the patient's screening and clinic's infrastructure have been improvised from time to time, according to the latest government's standard operating procedure (SOP); all of these are integral to reduce the infection risk posed by this virus. In a way, COVID-19 has brought improvements in dental practice especially in terms of infection prevention and reactions to future contagious diseases by means of the reinforcement of PPE implementation and development of more effective infection control measures [10].

According to the Centre of Disease Control and Prevention (CDC), dental school educational activities are bound to low-risk activities such as online case study as well as higher risk activities such as aerosol-generating procedures in the clinic [6]. By means of this, dental students are also exposed to the same threats as dental practitioners since they are treating patients during their clinical years to complete their clinical requirements. There are currently 13 institutions in Malaysia, either government or private higher institutions, that offer dentistry as a formal degree. Given the context that the dental students have a high risk of being in close contact with affected people during the clinical dental practice amidst this pandemic, they need to have sufficient knowledge on COVID-19 as this is believed to influence their precautionary behaviors. Unfortunately, a study regarding Malaysian's dental student knowledge about COVID-19 was limited to a particular university in this region [3]. Therefore, this study aims to extend the research in determining the knowledge status of dental students in Malaysia regarding COVID-19's mode of transmission, diagnosis, treatment, signs, and symptoms; their perceived risk of COVID19 as threats to them as an individual or towards their family; and their preventive or precautionary behaviors to break the COVID-19 chain of infection during this pandemic.

\section{Materials and Methods}

\subsection{Ethical Aspect}

Ethical approval was obtained from the IIUM Research Ethics Committee on 21st January 2021 (Ref. No: IREC 2021-013).

\subsection{Study Design}

This cross-sectional study was conducted among dental students in Malaysia through an online survey by creating a Google Form to allow respondents to access the questionnaire with ease.

\subsection{Sampling Method}

The sampling method used was convenience sampling which is a type of nonprobability sampling. By using this sampling method, the members of the population freely participated based on their availability and accessibility to the survey instrument.

\subsection{Inclusion and Exclusion Criteria}

The inclusion criteria for this study were dental students in Malaysia. The exclusion criteria for this study were respondents who submitted incomplete survey questionnaires or denied the consent to participate. 


\subsection{Sample Size}

The target population was dental students from public and private universities in Malaysia. From a calculation using Raosoft ${ }^{\circledR}$ software (Raosoft Inc, Seattle, WA, USA) (http: / / www.raosoft.com/samplesize.html) (accessed on 1 December 2020), the recommended sample size for this study was 347 students based on the population size of 3514 Malaysian dental students with a confidence level of 95 and a 5\% acceptable margin of error.

\subsection{Data Collection}

The study was conducted through an online survey using Google Form. Beginning on 11 March 2021, this study was completed on 30 April 2021. The questionnaire consisted of four sections as follows:

- Section 1: Demographic background

This section consisted of eight items, including age, gender, nationality, ethnicity, current location, year, and phase of study (clinical or preclinical).

- $\quad$ Section 2: Knowledge on COVID-19

This section was adapted based on the questionnaire from a local study by Wee et al. (2020) and a multi-country study by Ammar et al. (2020) with some modifications according to the Ministry of Health Malaysia guidelines [3,11]. There were six items that consisted of 'True' and 'False' questions. These items evaluated the knowledge of COVID-19 related to the incubation period, vulnerable groups, signs and symptoms, transmission routes, preventive measures, diagnosis, and treatment with a total score of 26 points. Correct responses to questions were summed up and a final percentage was calculated on a 100point scale. A score $>80 \%$ was designated as high, $60-80 \%$ as moderate, and $<60 \%$ as poor knowledge [3].

\section{- $\quad$ Section 3: Perceived risk}

This section used the COVID-19 Perceived Risk Scale or CPRS, a scale developed for assessing COVID-19-related perceived risk [12]. The CPRS consisted of eight items, each rated on a five-point Likert scale ranging between 1 (negligible) and 5 (very large). The section included a cognitive dimension and emotional dimension. Higher scores reflected higher levels of personal perceived risk related to COVID-19.

\section{- $\quad$ Section 4: Preventive behaviors}

This section was adapted based on the questionnaire from a local study by Wee et al. (2020) [3]. There were 17 statements with a five-point Likert scale ranging between 1 (certainly no) and 5 (definitely yes). All items focused on the preventive practices of respondents during the COVID-19 pandemic. A high score reflected a good level of preventive behaviors during the pandemic.

\subsection{Testing Validity and Reliability of Questionnaire}

A face-to-face validity was conducted by asking five dental students at the International Islamic University Malaysia (IIUM) to answer the questionnaire. This phase was conducted to test and judge the items of the study instrument in terms of clarity of wording, readability, and likelihood of respondents answering the questions. The questionnaire was edited accordingly after the face-to-face validation. A pilot study was then carried out among 42 IIUM dental students as a preliminary analysis to evaluate the reliability of the questionnaire using Cronbach's alpha.

\subsection{Statistical Analysis}

Data were analyzed using Microsoft Excel and SPSS statistical software (Version 25.0). Descriptive characteristics including age, gender, nationality, ethnicity, current location, institution, and year and phase of the study (clinical or preclinical) were analyzed. Differences between mean scores of knowledge, perceived risk, and preventive behavior 
scores between different sociodemographic characteristics of dental students were tested using the Mann-Whitney U test for two groups comparison and Kruskal Wallis test for three or more groups comparison since the data were not normally distributed. The level of significance was set at 0.05 with $95 \%$ confidence intervals.

\section{Results}

\subsection{Demographic Data}

This study comprised a total of 355 dental students in Malaysia. The sociodemographic characteristics of the respondents are presented in Table 1 . The majority of respondents were female $(76.9 \%)$, Malaysian students, and Malaysian ethnicity. The mean age was 22.40 years. Most of them (64.8\%) stayed on campus. The majority of respondents were year $4(31.0 \%)$, followed by year $5(21.1 \%)$. Clinical students accounted for the highest proportion $(62.8 \%)$ of the total respondents.

Table 1. Sociodemographic background.

\begin{tabular}{|c|c|c|}
\hline \multirow[b]{2}{*}{ Variables } & \multicolumn{2}{|c|}{ Frequency } \\
\hline & $\begin{array}{c}\mathrm{N} \\
\text { (Total }=355 \text { Respondents) }\end{array}$ & $\%$ \\
\hline \multicolumn{3}{|l|}{ Gender } \\
\hline Male & 82 & 23.1 \\
\hline Female & 273 & 76.9 \\
\hline \multicolumn{3}{|l|}{ Age } \\
\hline$<22$ & 121 & 34.0 \\
\hline $22-25$ & 229 & 64.6 \\
\hline$>25$ & 5 & 1.4 \\
\hline \multicolumn{3}{|l|}{ Nationality } \\
\hline Malaysian & 351 & 98.9 \\
\hline International & 4 & 1.1 \\
\hline \multicolumn{3}{|l|}{ Ethnicity } \\
\hline Malay & 270 & 76.1 \\
\hline Chinese & 60 & 16.9 \\
\hline Indian & 14 & 3.9 \\
\hline Others & 11 & 3.1 \\
\hline \multicolumn{3}{|l|}{ Current location } \\
\hline Off campus & 125 & 35.2 \\
\hline On campus & 230 & 64.8 \\
\hline \multicolumn{3}{|l|}{ Year of study } \\
\hline 1 & 72 & 20.3 \\
\hline 2 & 53 & 14.9 \\
\hline 3 & 45 & 12.7 \\
\hline 4 & 110 & 31.0 \\
\hline 5 & 75 & 21.1 \\
\hline \multicolumn{3}{|l|}{ Phase of study } \\
\hline Preclinical & 132 & 37.2 \\
\hline Clinical & 223 & 62.8 \\
\hline
\end{tabular}

\subsection{Knowledge of COVID-19}

Table 2 shows all true-false statements which were given to test the knowledge of dental students of COVID-19. The majority of respondents answered correctly for all questions asked except for a few questions regarding COVID-19 transmission (76.3\% selected 'True' for touching body fluid of an infected patient, $78.0 \%$ selected 'False' for touching domestic pets, and $74.9 \%$ selected 'True' for touching objects that an infected person has touched) and possible signs or symptoms of COVID-19 infection (67.9\% selected 'True' for muscle or joint pain, $61.7 \%$ selected 'False' for dry mouth). 
Table 2. Knowledge of COVID-19.

\begin{tabular}{|c|c|}
\hline Statements & $\begin{array}{c}\text { Correct } \\
\text { Responses } \\
\text { N (\%) }\end{array}$ \\
\hline Incubation period of COVID-19 is up to 14 days. * & $326(91.8)$ \\
\hline \multicolumn{2}{|l|}{ Vulnerability to COVID-19: } \\
\hline Only older adults can become infected with COVID-19. & $331(93.2)$ \\
\hline Older adults are the group with highest mortality when infected with COVID-19. * & $322(90.7)$ \\
\hline Those with other health problems more likely to die from COVID-19 than those without any other health problems. * & $344(96.9)$ \\
\hline \multicolumn{2}{|l|}{ Regarding COVID-19 diagnosis and treatment: } \\
\hline It can be diagnosed by PCR test on samples collected from nasal/pharyngeal swab. * & $353(99.4)$ \\
\hline The disease can be solely treated by using antiviral drugs. & $299(84.2)$ \\
\hline \multicolumn{2}{|l|}{ COVID-19 can be transmitted through: } \\
\hline Direct contact with aerosol splattered during a dental procedure in an infected patient. ${ }^{*}$ & $337(94.9)$ \\
\hline Inhaling air from an infected patient. * & $285(80.3)$ \\
\hline Touching body fluids of an infected patient. * & $271(76.3)$ \\
\hline Touching domestic pets (e.g., cat, dog, etc.). & $277(78.0)$ \\
\hline Touching objects that have been touched by an infected person. ${ }^{*}$ & $266(74.9)$ \\
\hline Breathing in droplets exhaled or coughed from an infected person. * & $355(100.0)$ \\
\hline \multicolumn{2}{|l|}{ Possible signs or symptoms of COVID-19 infection: } \\
\hline Nose bleeds & $338(95.2)$ \\
\hline Cough * & $353(99.4)$ \\
\hline Dry mouth & $219(61.7)$ \\
\hline Fever* & $351(98.9)$ \\
\hline Muscle or joint pain * & $241(67.9)$ \\
\hline Shortness of breath * & $348(98.0)$ \\
\hline Sore throat* & $341(96.1)$ \\
\hline Loss of smell and taste sensation * & $344(96.9)$ \\
\hline \multicolumn{2}{|l|}{ Ways to prevent COVID-19 infection: } \\
\hline Getting a vaccination against pneumonia & $250(70.4)$ \\
\hline Wearing a facemask * & $354(99.7)$ \\
\hline Washing your hands* & $355(100.0)$ \\
\hline Avoiding close contact with people who are sick* & $351(98.9)$ \\
\hline Taking antibiotics & $305(85.9)$ \\
\hline Avoiding touching your eyes, nose and mouth with unwashed hands * & $352(99.2)$ \\
\hline
\end{tabular}

\footnotetext{
* Correct statement.
}

\subsection{Perceived Risk}

Table 3 comprises five questions on the perceived risks of COVID-19. Most respondents were worried and extremely worried about the possibility of their family members contracting COVID-19 and the disease becoming a health issue. In total, 33.5\% were worried and extremely worried (33.0\%) about themselves contracting COVID-19. The majority of the respondents perceived moderate $(36.9 \%)$ to high $(29.0 \%)$ chances of acquiring COVID-19 compared to other persons. Most of the respondents perceived a low (36.3\%) to moderate (37.5\%) risk of dying from COVID-19.

\subsection{Preventive Behaviors}

Table 4 depicts the preventive behaviors practiced by the respondents during the COVID-19 pandemic. The majority of the students practiced preventive behaviors against COVID-19. Besides that, $37.2 \%$ would certainly wash their hands regularly according to the recommended time; however, $29.9 \%$ were indecisive about practicing cleaning and disinfecting items that can be easily touched by hands. In total, $53.5 \%$ of the respondents would not usually greet people with a handshake, while $67.3 \%$ would not usually greet people with a hug. 
Table 3. Perceived risk of COVID-19.

\begin{tabular}{|c|c|c|c|c|c|c|c|}
\hline Questions & $\begin{array}{c}1 \\
N(\%)\end{array}$ & $\begin{array}{c}2 \\
N(\%)\end{array}$ & $\begin{array}{c}3 \\
N(\%)\end{array}$ & $\begin{array}{c}4 \\
\mathrm{~N}(\%)\end{array}$ & $\begin{array}{c}5 \\
N(\%)\end{array}$ & Mean & SD \\
\hline $\begin{array}{l}\text { How worried are you about your family } \\
\text { member contracting COVID-19? }\end{array}$ & $2(0.6)$ & $10(2.8)$ & $26(7.3)$ & $90(25.4)$ & $227(63.9)$ & 4.49 & 0.797 \\
\hline $\begin{array}{l}\text { How worried are you about COVID-19 } \\
\text { emerging as a health issue? }\end{array}$ & $4(1.1)$ & $5(1.4)$ & $36(10.1)$ & $129(36.3)$ & $181(51.0)$ & 4.35 & 0.807 \\
\hline $\begin{array}{l}\text { How worried are you about contracting } \\
\text { COVID-19? }\end{array}$ & $8(2.3)$ & $26(7.3)$ & 85 (23.9) & 119 (33.5) & $117(33.0)$ & 3.88 & 1.026 \\
\hline $\begin{array}{l}\text { Compared to other persons, what would you } \\
\text { say about your chances for acquiring } \\
\text { COVID-19? }\end{array}$ & $14(3.9)$ & 68 (19.2) & 131 (36.9) & $103(29.0)$ & 39 (11.0) & 3.24 & 1.012 \\
\hline $\begin{array}{l}\text { What is the likelihood that you would die } \\
\text { from COVID-19? }\end{array}$ & 63 (17.7) & $129(36.3)$ & $133(37.5)$ & $20(5.6)$ & $10(2.8)$ & 2.39 & 0.937 \\
\hline
\end{tabular}

1 (negligible), 5 (very large), SD: standard deviation.

Table 4. Preventive behaviors against COVID-19.

\begin{tabular}{|c|c|c|c|c|c|c|c|}
\hline Statement & $\begin{array}{c}1 \\
\text { N (\%) }\end{array}$ & $\begin{array}{c}2 \\
\text { N (\%) }\end{array}$ & $\begin{array}{c}3 \\
\mathbf{N}(\%)\end{array}$ & $\begin{array}{c}4 \\
\text { N (\%) }\end{array}$ & $\begin{array}{c}5 \\
\text { N (\%) }\end{array}$ & Mean & SD \\
\hline $\begin{array}{l}\text { I usually put on a face mask whenever I go } \\
\text { out in public. }\end{array}$ & $0(0)$ & $0(0)$ & $2(0.6)$ & $16(4.5)$ & 337 (94.9) & 4.94 & 0.807 \\
\hline $\begin{array}{l}\text { If I find that I was in contact with an infected } \\
\text { person, I agree to be quarantined as } \\
\text { instructed by health authorities. }\end{array}$ & $1(0.3)$ & $1(0.3)$ & $9(2.5)$ & 43 (12.1) & $301(84.8)$ & 4.81 & 0.507 \\
\hline $\begin{array}{l}\text { If I find that I was in contact with an infected } \\
\text { person, I will inform the health authorities. }\end{array}$ & $1(0.3)$ & $3(0.8)$ & $18(5.1)$ & 55 (15.5) & $278(78.3)$ & 4.71 & 0.628 \\
\hline $\begin{array}{l}\text { If I have any of the symptoms associated } \\
\text { with the disease, I will inform the health } \\
\text { authorities. }\end{array}$ & $0(0)$ & $4(1.1)$ & $24(6.8)$ & 68 (19.2) & $259(73.0)$ & 4.64 & 0.659 \\
\hline $\begin{array}{l}\text { I practice physical distancing whenever I go } \\
\text { out in public. }\end{array}$ & $0(0)$ & $2(0.6)$ & $25(7.0)$ & $123(34.6)$ & 205 (57.7) & 4.50 & 0.653 \\
\hline $\begin{array}{l}\text { I am willing to undergo a COVID-19 test } \\
\text { although I am not instructed to (e.g., back } \\
\text { from travelling or red zone). }\end{array}$ & $6(1.7)$ & $10(2.8)$ & 41 (11.5) & $74(20.8)$ & $224(63.1)$ & 4.41 & 0.920 \\
\hline $\begin{array}{l}\text { I discuss COVID-19 prevention with my } \\
\text { family and friends. }\end{array}$ & $0(0)$ & $11(3.1)$ & $35(9.9)$ & $117(33.0)$ & $192(54.1)$ & 4.38 & 0.788 \\
\hline $\begin{array}{l}\text { I follow the updates about the spread of the } \\
\text { virus in Malaysia. }\end{array}$ & $3(0.8)$ & $17(4.8)$ & 38 (10.7) & $126(35.5)$ & $171(48.2)$ & 4.25 & 0.891 \\
\hline $\begin{array}{l}\text { I wash my hands regularly and for enough } \\
\text { period of time. }\end{array}$ & $3(0.8)$ & $16(4.5)$ & 77 (21.7) & $127(35.8)$ & $132(37.2)$ & 4.04 & 1.026 \\
\hline $\begin{array}{l}\text { I follow the updates about the spread of the } \\
\text { virus worldwide. }\end{array}$ & $7(2.0)$ & 31 (8.7) & $100(28.2)$ & 91 (25.6) & $126(35.5)$ & 3.84 & 1.068 \\
\hline $\begin{array}{l}\text { I practice cleaning and disinfecting items that } \\
\text { can be easily touched with hands (i.e., door } \\
\text { handles, lift buttons, and table surfaces). }\end{array}$ & $7(2.0)$ & 44 (12.4) & $106(29.9)$ & $103(29.0)$ & $95(26.8)$ & 3.66 & 0.797 \\
\hline $\begin{array}{l}\text { When I meet other people, I usually greet } \\
\text { them with a handshake. * }\end{array}$ & $190(53.5)$ & $112(31.5)$ & $31(8.7)$ & $15(4.2)$ & $7(2.0)$ & 1.70 & 1.012 \\
\hline $\begin{array}{l}\text { When I meet other people, I usually greet } \\
\text { them with a hug. * }\end{array}$ & $239(67.3)$ & 85 (23.9) & $20(5.6)$ & $9(2.5)$ & $5(0.6)$ & 1.45 & 0.937 \\
\hline
\end{tabular}

1 (certainly no), 5 (definitely yes), * Statements indicating behaviors that should be avoided. SD: standard deviation.

\subsection{Knowledge, Perceived Risk, and Preventive Behavior Scores}

Table 5 summarizes the average percentages of knowledge and scores for perceived risk and preventive behaviors. In total, $93.5 \%$ of respondents scored a high score for knowledge of COVID-19, 6.50\% obtained an average score, while none of the respondents scored poorly in this section. Mean scores for students' knowledge about COVID-19 was $23.29 \pm 1.76$, out of 25 total scores. The highest score attained was $100 \%$, and the lowest 
attained score was $65.4 \%$. Concerning perceived risk and preventive behaviors, overall respondents scored a mean of $18.35 \pm 3.05$ out of an overall score of 25 , and $57.03 \pm 5.67$, out of an overall score of 65 , respectively.

Table 5. Knowledge of COVID-19, perceived risk, and preventive behaviors of dental students in Malaysia.

\begin{tabular}{ll}
\hline Variable & N (\%) \\
\hline Knowledge Scores (0-100\%) & \\
High (>80\%) (21-26) & $332(93.5)$ \\
Moderate (60-80\%) (17-20) & $23(6.50)$ \\
Poor (<60\%) (0-16) & $0(0.0)$ \\
Minimum & $17(65.4)$ \\
Maximum & $26(100)$ \\
Mean \pm SD & $23.29 \pm 1.76$ \\
\hline Perceived Risk Scores (5-25) & \\
Mean \pm SD & $18.35 \pm 3.05$ \\
\hline Preventive Behaviors Scores (13-65) & \\
Mean \pm SD & $57.03 \pm 5.67$ \\
\hline
\end{tabular}

\subsection{Association between Demographic Background and Each Domain Score}

Table 6 shows the mean score of knowledge, perceived risk, and preventive behaviors, according to the sociodemographic characteristics of dental students. The mean scores of perceived risks were significantly higher among female respondents $(18.66 \pm 2.914)$ than males $(17.33 \pm 3.293)(p=0.001)$. Similarly, females had a significantly higher mean preventive behavior score $(57.70 \pm 5.318)$ than the males $(54.80 \pm 6.235)(p=0.000)$. All dependent variables were not significantly different $(p>0.05)$ with nationality (Malaysian or international). With regards to ethnicity, significant differences were found with the knowledge and perceived risk scores among the respondents from various ethnic groups. Chinese respondents had the highest mean knowledge score among ethnic groups with $23.87 \pm 1.556$ as compared to other groups $(p=0.0190)$. In contrast to knowledge, Malay respondents (18.74 \pm 2.905$)$ had a better perceived risk score compared to other groups $(p=0.000)$. In terms of preventive behaviors, the mean score was not significantly different $(p>0.05)$ across ethnicities. Interestingly, students who were on campus scored significantly higher in knowledge $(p=0.013)$, and perceived risk score $(p=0.010)$, but significantly lower for preventive behaviors $(p=0.009)$. Knowledge and perceived risk score significantly differed according to the year and phase of study. The mean score for knowledge was higher among clinical students as compared to preclinical students $(p=0.000)$. Year 5 students had the highest knowledge mean score $(p=0.000)$ and the best perceived risk scores $(p=0.041)$, followed by year 4 , year 3 , year 2 , and year 1 students. No significant difference was found in the mean preventive behavior scores when comparisons were made between students across years and phases of study.

Table 6. Knowledge, perceived risk, and preventive behaviour scores according to sociodemographic profiles of dental students.

\begin{tabular}{|c|c|c|c|c|c|c|c|}
\hline \multirow{2}{*}{$\begin{array}{l}\text { Sociodemographic } \\
\text { Characteristics }\end{array}$} & \multirow{2}{*}{$\mathbf{N}$} & \multicolumn{2}{|c|}{ Knowledge Score } & \multicolumn{2}{|c|}{ Perceived Risks Score } & \multicolumn{2}{|c|}{ Preventive Behaviors Score } \\
\hline & & Mean (SD) & $p$-Value & Mean (SD) & $p$-Value & Mean (SD) & $p$-Value \\
\hline \multicolumn{8}{|l|}{ Gender } \\
\hline Male & 82 & $23.22(1.722)$ & 0.517 & $17.33(3.293)$ & $0.001 *$ & $54.80(6.235)$ & $0.000 *$ \\
\hline Female & 273 & $23.31(1.768)$ & & $18.66(2.914)$ & & $57.70(5.318)$ & \\
\hline \multicolumn{8}{|l|}{ Nationality } \\
\hline Malaysian & 351 & $23.29(1.761)$ & 0.911 & $18.36(3.051)$ & 0.263 & $57.03(5.672)$ & 0.731 \\
\hline International & 4 & $23.50(1.291)$ & & $17.00(3.367)$ & & $56.50(5.972)$ & \\
\hline
\end{tabular}


Table 6. Cont.

\begin{tabular}{|c|c|c|c|c|c|c|c|}
\hline \multirow{2}{*}{$\begin{array}{l}\text { Sociodemographic } \\
\text { Characteristics }\end{array}$} & \multirow{2}{*}{$\mathbf{N}$} & \multicolumn{2}{|c|}{ Knowledge Score } & \multicolumn{2}{|c|}{ Perceived Risks Score } & \multicolumn{2}{|c|}{ Preventive Behaviors Score } \\
\hline & & Mean (SD) & $p$-Value & Mean (SD) & $p$-Value & Mean (SD) & $p$-Value \\
\hline \multicolumn{8}{|l|}{ Ethnicity } \\
\hline Malay & 270 & $23.13(1.810)$ & \multirow{4}{*}{$0.019 *$} & $18.74(2.905)$ & \multirow{4}{*}{$0.000 *$} & $56.91(5.411)$ & \multirow{4}{*}{0.569} \\
\hline Chinese & 60 & $23.87(1.556)$ & & $16.68(3.392)$ & & $57.55(6.080)$ & \\
\hline Indian & 14 & $23.43(1.342)$ & & $18.71(2.164)$ & & $57.07(8.880)$ & \\
\hline Others & 11 & $23.82(1.168)$ & & $17.27(2.573)$ & & $57.09(5.147)$ & \\
\hline \multicolumn{8}{|l|}{ Current location } \\
\hline On campus & 125 & $23.47(1.686)$ & \multirow[t]{2}{*}{$0.013 *$} & $18.69(2.905)$ & \multirow[t]{2}{*}{$0.010 *$} & $56.39(6.013)$ & \multirow[t]{2}{*}{$0.009 *$} \\
\hline Off campus & 230 & $22.96(1.838)$ & & $17.72(3.224)$ & & $58.21(4.768)$ & \\
\hline \multicolumn{8}{|l|}{ Year of study } \\
\hline Year 1 & 72 & $22.18(1.841)$ & \multirow{5}{*}{$0.000 *$} & $17.79(3.131)$ & \multirow{5}{*}{0.041 * } & $58.13(4.850)$ & \multirow{5}{*}{0.565} \\
\hline Year 2 & 53 & $22.58(1.737)$ & & $17.72(3.416)$ & & $56.81(6.382)$ & \\
\hline Year 3 & 45 & $23.60(1.468)$ & & $18.04(2.611)$ & & $56.73(4.721)$ & \\
\hline Year 4 & 110 & $23.74(1.572)$ & & $18.71(3.081)$ & & $56.66(6.055)$ & \\
\hline Year 5 & 75 & $24.01(1.419)$ & & 18.99 (2.773) & & $56.84(5.803)$ & \\
\hline \multicolumn{8}{|l|}{ Phase of study } \\
\hline Preclinical & 132 & $22.40(1.786)$ & \multirow[t]{2}{*}{$0.000 *$} & $17.68(3.298)$ & \multirow[t]{2}{*}{$0.004 *$} & $57.64(5.504)$ & \multirow[t]{2}{*}{0.093} \\
\hline Clinical & 223 & $23.82(1.512)$ & & $18.74(2.832)$ & & $56.66(5.742)$ & \\
\hline
\end{tabular}

${ }^{*} p<0.05$, Mann-Whitney $\mathrm{U}$ test for two groups comparison and Kruskal Wallis test for three or more groups comparison, SD: standard deviation.

\section{Discussion}

Dental education is facing a great impact due to the sudden halt in the educational activities because of the COVID-19 pandemic. The majority of dental schools worldwide suspended activities to minimize the transmission of the virus [13]. New oral health policies were implemented including strict infection control measures, postponing nonemergency treatment, and upgrading ventilation systems [14]. Besides that, the clinical competence and academic performance of dental students were negatively affected due to the suspension of the usual face-to-face teaching activities [9]. As COVID-19 stays, and with the emergence of a vaccination plan in Malaysia, dental schools have re-opened following the need of students to complete their clinical requirements for graduation. However, at this point of time, the knowledge status, perceived risk, and preventive behaviors amongst dental students in Malaysia are not yet known.

To the best of our knowledge, this is the first study in Malaysia that discusses knowledge, perceived risk, and preventive behaviors during the COVID-9 pandemic among dental students throughout Malaysia. Our study provides an overview of the knowledge of dental students who have a high risk of infection during the clinical dental practice, which involves rotative instruments and aerosol build-up. Lacking in knowledge, perceived risk, and preventive measures can threaten dental staff and the patients' safety and health which may deteriorate the health care system.

The current study showed that most respondents (93.5\%) had a high level of knowledge by scoring $80 \%$ and above, while the rest showed a moderate level of knowledge (6.5\%). Similarly, the high knowledge score was actually found in other studies among dental students from Palestine, Saudi Arabia, and Austria [15-17]. In another study conducted in Jordan, knowledge scores were significantly higher for medical and dental students than other disciplines such as pharmacy and nursing [18]. However, in comparison with a previous local study in Malaysia, it was demonstrated that only $55.2 \%$ of medical and dental students had high knowledge with scores of over $80 \%$, while the rest had moderate knowledge about COVID-19 [3]. The knowledge score was lower in this study compared to our current study, perhaps because this prior study was conducted in an earlier period of the COVID-19 pandemic in Malaysia. At that time, the knowledge of COVID-19 was by far still lacking and not well-disseminated. 
In our study, dental students had good knowledge of COVID-19 across multiple topics. The correct responses in all questions were $70 \%$ and above, showing that all students possessed a good understanding of COVID-19. However, regarding the symptoms related to COVID-19, there were two symptoms that less than $70 \%$ of students correctly identified: dry mouth $(61.7 \%)$ and muscle or joint pain (67.9\%). This is congruent with a previous study by Alawia et al. (2021) in which the questions about muscle or joint pain were correctly answered only by $50.2 \%$ of the students [15]. In fact, the WHO and CDC reported muscle or joint paint as the less-common symptoms of COVID-19. Even though dry mouth was not a symptom directly associated with COVID-19 infection, Freni et al. (2020) reported the signs of dry mouth in $32 \%$ of the COVID-19 patients, and in most cases, it occurred before other symptoms of the disease [19]. Most respondents recognized that antibiotics are ineffective in preventing COVID-19, probably because they understood that COVID-19 is a viral disease $[15,20]$.

Regarding sociodemographic characteristics and knowledge, our findings show no significant difference between male and female respondents' knowledge of COVID-19. Both groups recorded almost similar knowledge mean scores. This is aligned with the study conducted in a local university in Malaysia that found no significant association between gender and knowledge of COVID-19 [3]. On the contrary, the results of the study among dental students in Saudi Arabia showed a statistically significant difference in males' and females' knowledge, with females scoring better than males [16]. Another study in India also revealed significant differences in the mean scores of knowledge, where male dental students had higher mean knowledge scores than female students [21].

Overall, the knowledge score for the students significantly differed based on ethnicity, current location, year of study, and phase of study. In the present study, there was a significant difference between preclinical students and clinical students in the knowledge score, with the mean score being lower among preclinical students. Our results are in line with other research carried out among dental students in Turkey. There, they concluded knowledge, attitudes, and practices regarding COVID-19 did present a significant difference between preclinical and clinical students [22]. This is possibly due to the fact that clinical students who had started treating patients had better knowledge and attitudes towards infectious diseases owing to the extent of time they spent at the clinical setting, where they worked at a higher risk of exposure.

Perception towards risk, severity, and susceptibility plays an important role in determining an individual's preventive behaviors. [23]. In our study, the perceived risk towards COVID-19 was assessed by analyzing respondents' perceptions and comprehension on the risk imposed by COVID-19 on one's health in which about two-thirds of the respondents considered COVID-19 as a deadly disease. This is unlike a population-based survey in Iran, where only half of their respondents perceived COVID-19 as a serious issue, and this was believed to be associated with the lower level of knowledge during the conduct of that study [24]. We found that a higher proportion of respondents were concerned about their family's health, while less than a quarter assumed themselves at risk of contracting COVID-19. Consistent with a study from China, college students were more worried of their elder family members than themselves because the elderly are more vulnerable and have worse prognoses with COVID-19 infections [25]. We also found that almost half of the respondents assumed that they had the possibility of dying due to COVID-19. Similarly, $92.6 \%(\mathrm{n}=3720)$ of people in Anhui province, China, were agitated with the spread of COVID-19 [26]. These observations were supported by a few laboratory findings that proved an increase in death anxiety and preventive behaviors as a reflection of the current epidemics or virus outbreaks [27]. Death tolls of COVID-19 on the daily news were also considered as a factor that built fears of death among the public [28]. The increase in dental students' perceived risks were due to the novel nature of the virus, the lack of vaccines or effective treatments at the early pandemic phase, being near to untested patients, the high risk of inhaling respiratory droplets and saliva in the confined space of the dental 
unit, and the lack of awareness regarding the disease and precautionary measures among patients $[9,29]$.

Our study also revealed that more female students showed higher scores in perceived risks and preventive behaviors, with average scores of 18.66 and 57.70, respectively, as compared to male students with average scores of 17.33 and 54.80, respectively. In corroboration with this finding, a survey among medical and dental students of a local university in Malaysia showed a relatively higher number of female students who practiced positive attitudes and preventive behaviors than male students [3]. Higher risk perceptions among females can be described by their unfeasible thoughts, gender socialization, and high sensitivity towards the health risks $[25,30]$. Few previous reports showed unparallel findings on how students' locations were affecting their perceived risks. A former study explained that the students from the outbreak region had higher risk perception than the non-epidemic region, while our findings revealed that students who stayed on the campus had a higher perceived risk mean score than those at home [25]. Besides that, our survey found a significant difference in the risk perception of students in the clinical phase compared with students in the preclinical phase, in which the former had a higher mean score of perceived risks than the latter. Students with comprehensive knowledge were more aware of the risk and had a higher risk perception of COVID-19 [25]. Hence, a good understanding of this pandemic directly affects the perception of risk and preventive practices.

In accordance with preventive measures recommended by the WHO, generally students performed good preventive behaviors. The majority of the respondents would definitely wear a mask and practice physical distancing in public, and they would follow health authorities' instructions. In order to break the chain of infection, about half of the respondents practiced regular hand washing and disinfecting items that can be easily touched with hands. Generally, the respondents strongly agreed that handshaking and hugging should not be practiced during this death-dealing situation. A study conducted on preventive health behaviors during the COVID-19 pandemic based on the Health Belief Model among Egyptians showed that highly-educated persons have better preventive behavior. This is because they have higher knowledge about the disease, better-perceived susceptibility, and low perceived barriers [31]. The results also proved that students were eager to keep themselves updated with COVID-19 updates either locally or globally.

Our study also highlighted that COVID-19 protective measures significantly differed by gender and students' current location. Few previous studies proved that female students practiced more preventive behaviors compared to male students [3,32]. However, a study based in India had a different view and concluded that women in Bihar, India had less knowledge; therefore, they were less likely to practice preventive behaviors due to limited and challenging access to receive accurate information. Regarding students' current location, students living off-campus had higher preventive behavior scores than students living on-campus. Those staying on campus perhaps generally regard the campus as a safe environment, and those staying off campus generally need to travel, which exposes them to a higher risk of infection. No significant difference was found between preventive behavior scores of those clinical and preclinical students. In contrast, a study among medical students in Jordan reported that clinical students practiced more protective measures, such as using disinfectants, than the preclinical students [33].

Overall, this study has some limitations in that the convenience sampling method used in this study may reduce the statistical representativeness. However, convenience sampling is the most feasible method for this study to sample dental students across the whole country as there is no centralized listing of all dental students available. Despite this, this study managed to acquire dental students from most dental schools in Malaysia through dental students societies representatives. Secondly, the cross-sectional design of this study may not always cover the knowledge on COVID-19 during the pandemic. Another challenge is that the knowledge on this area is continually evolving as more new findings are discovered each day. Even though this study showed that dental students in Malaysia 
possessed good knowledge on COVID-19, with the continued growth of knowledge on COVID-19, dental students should keep abreast of all the recent developments.

\section{Conclusions}

In summary, most dental students in Malaysia have good knowledge about COVID19. Hence, their perceived risk of the disease is high, and they are effectively practicing preventive behaviors. However, with the accumulating new knowledge on COVID-19, the latest information on this disease should be incorporated into dental schools' curriculums and updated from time to time.

Author Contributions: Conceptualization, A.I. and C.S.; methodology, A.I., A.F.I., W.L., and C.S.; software, A.I.; validation, C.S. and A.I.; formal analysis, N.H.I. and N.Y.M.A.K.; investigation, N.H.I., N.Y.M.A.K.; data curation, N.H.I. and N.Y.M.A.K.; writing-original draft preparation, N.H.I. and N.Y.M.A.K.; writing—review and editing, A.I. and C.S.; supervision, A.I., W.L., A.F.I., and C.S. All authors have read and agreed to the published version of the manuscript.

Funding: This research received no external funding.

Institutional Review Board Statement: The study was conducted according to the guidelines of the Declaration of Helsinki, and approved by IIUM Research Ethics Committee on 21 January 2021 (Ref. No: IREC 2021-013).

Informed Consent Statement: Informed consent was obtained from all subjects involved in the study.

Data Availability Statement: Data of the study will be shared upon request to the corresponding author.

Acknowledgments: We are thankful to all student representatives from each university who have contributed to disseminating the survey.

Conflicts of Interest: The authors declare no conflict of interest.

\section{References}

1. Chan, J.F.W.; Yuan, S.; Kok, K.H.; To, K.K.W.; Hin, C.; Yang, J.; Xing, F.; Liu, J.; Yip, C.C.Y.; Poon, R.W.S.; et al. A familial cluster of pneumonia associated with the 2019 novel coronavirus indicating person-to-person transmission: A study of a family cluster. Lancet 2020, 395, 514-523. [CrossRef]

2. World Health Organization. WHO Director-General's Opening Remarks at the Media Briefing on COVID-19. 11 March 2020. Available online: https:/ / www.who.int/dg/speeches/detail/who-director-general-s-opening-remarks-at-the-media-briefingon-covid-19---11-march-2020 (accessed on 12 September 2021).

3. Wee, E.G.; Giri, M.S.; Sundram, T.K.; Venudran, C.V. COVID-19: Knowledge, attitude and preventive behaviors of medical and dental students. Int. J. Biomed. Clin. Sci. 2020, 5, 236-256.

4. Ministry of Health Malaysia. 2021. Available online: http:// covid-19.moh.gov.my/ (accessed on 12 September 2021).

5. Elengoe, A. COVID-19 outbreak in Malaysia. Osong Public Health Res. Perspect. 2020, 11, 93-100. [CrossRef]

6. Hung, M.; Licari, F.W.; Hon, E.S.; Lauren, E.; Su, S.; Birmingham, W.C.; Wadsworth, L.L.; Lasetter, J.H.; Graff, T.C.; Harman, W.; et al. In an era of uncertainty: Impact of COVID-19 on dental education. J. Dent. Edu. 2020, 85, 148-156. [CrossRef] [PubMed]

7. Ali, S.; Zeb, U.; Muhammad, A. Transmission Routes and Infection Control of Novel Coronavirus-2019 in Dental Clinics-A Review. J. Islamabad Med Dent. Coll. 2020, 9, 65-72.

8. Azzi, L.; Carcano, G.; Gianfagna, F.; Grossi, P.; Gasperina, D.D.; Genoni, A.; Fasano, M.; Sessa, F.; Tettamanti, L.; Carinci, F.; et al. Saliva is a reliable tool to detect SARS-CoV-2. J. Infect. 2020, 81, e45-e50. [CrossRef]

9. Jum'ah, A.A.; Elsalem, L.; Loch, C.; Schwass, D.; Brunton, P.A. Perception of health and educational risks amongst dental students and educators in the era of COVID-19. Eur. J. Dent. Educ. 2021, 25, 506-515. [CrossRef]

10. Loch, C.; Kuan, I.B.J.; Elsalem, L.; Schwass, D.; Brunton, P.A.; Jum'ah, A. COVID-19 and dental clinical practice: Students and clinical staff perceptions of health risks and educational impact. J. Dent. Educ. 2021, 85, 44-52. [CrossRef] [PubMed]

11. Ammar, N.; Aly, N.M.; Folayan, M.O.; Khader, Y.; Virtanen, J.I.; Al-Batayneh, O.B.; Mohebbi, S.Z.; Attia, S.; Howaldt, H.P.; Boettger, S.; et al. Behavior change due to COVID-19 among dental academics-The theory of planned behavior: Stresses, worries, training, and pandemic severity. PLoS ONE. 2020, 15, e0239961. [CrossRef]

12. Yıldırım, M.; Güler, A. Factor analysis of the COVID-19 Perceived Risk Scale: A preliminary study. Death Stud. 2020, 25, 1-8. [CrossRef] [PubMed]

13. Brondani, M.; Donnelly, L. COVID-19 pandemic: Students' perspectives on dental geriatric care and education. J. Dent. Educ. 2020, 84, 1237-1244. [CrossRef] [PubMed] 
14. Jiang, C.M.; Duangthip, D.; Auychai, P.; Chiba, M.; Folayan, M.O.; Hamama, H.H.H.; Kamnoedboon, P.; Lyons, K.; Matangkasombut, O.; Mathu-Muju, K.; et al. Changes in Oral Health Policies and Guidelines During the COVID-19 Pandemic. Front. Oral. Health 2021, 2, 668444. [CrossRef]

15. Alawia, R.; Riad, A.; Kateeb, E. Knowledge and attitudes among dental students about COVID-19 and its precautionary measures: A cross-sectional study. J. Oral Med. Oral Surg. 2020, 27, 17. [CrossRef]

16. Almulhim, B.; Alassaf, A.; Alghamdi, S.; Alroomy, R.; Aldhuwayhi, S.; Aljabr, A.; Mallineni, S.K. Dentistry amidst the COVID-19 pandemic: Knowledge, attitude, and practices among the Saudi Arabian dental students. Front. Med. 2021, 8, 654524. [CrossRef] [PubMed]

17. Boukhobza, S.; Ritschl, V.; Stamm, T.; Bekes, K. The COVID-19 Pandemic and its impact on knowledge, perception and attitudes of dentistry students in Austria: A cross-sectional survey. J. Multidiscip. Healthc. 2021, 14, 1413-1422. [CrossRef] [PubMed]

18. Mustafa, R.M.; Alrabadi, N.N.; Alshali, R.Z.; Khader, Y.S.; Ahmad, D.M. Knowledge, Attitude, Behavior, and Stress Related to COVID-19 among Undergraduate Health Care Students in Jordan. Eur. J. Dent. 2020, 14 (Suppl. 01), S50-S55. [CrossRef]

19. Freni, F.; Meduri, A.; Gazia, F.; Nicastro, V.; Galletti, C.; Aragona, P.; Galletti, B.; Galletti, F. Symptomatology in head and neck district in coronavirus disease (COVID-19): A possible neuroinvasive action of SARS-CoV-2. Am. J. Otolaryngol. 2020, $41,102612$. [CrossRef]

20. Gallè, F.; Sabella, E.A.; Da Molin, G.; De Giglio, O.; Caggiano, G.; Di Onofrio, V.; Ferracuti, S.; Montagna, M.T.; Liguori, G.; Orsi, G.B.; et al. Understanding knowledge and behaviors related to COVID-19 epidemic in Italian undergraduate students: The EPICO Study. Int. J. Environ. Res. Public Health 2020, 17, 3481. [CrossRef]

21. Batra, K.; Urankar, Y.; Batra, R.; Gomes, A.F.; Meru, S.; Kaurani, P. Knowledge, protective behaviors and risk perception of COVID-19 among dental students in India: A cross-sectional analysis. Healthcare 2021, 9, 574. [CrossRef]

22. Ataş, O.; Talo Yildirim, T. Evaluation of knowledge, attitudes, and clinical education of dental students about COVID-19 pandemic PeerJ 2020, 8, e9575. [CrossRef]

23. Glanz, K.; Rimer, B.K.; Viswanath, K. Health Behavior and Health Education: Theory, Research, and Practice, 4th ed.; Jossey-Bass: San Francisco, CA, USA, 2008; p. 96. ISBN 978-0-470-43248-8.

24. Honarvar, B.; Lankarani, K.B.; Kharmandar, A.; Shaygani, F.; Zahedroozgar, M.; Rahmanian Haghighi, M.R.; Ghahramani, S.; Honarvar, H.; Daryabadi, M.M.; Salavati, Z.; et al. Knowledge, attitudes, risk perceptions, and practices of adults toward COVID-19: A population and field-based study from Iran. Int. J. Public Health 2020, 65, 731-739. [CrossRef]

25. Ding, Y.; Du, X.; Li, Q.; Zhang, M.; Zhang, Q.; Tan, X.; Liu, Q. Risk perception of coronavirus disease 2019 (COVID-19) and its related factors among college students in China during quarantine. PLoS ONE. 2020, 15, e0237626. [CrossRef]

26. Chen, Y.; Jin, Y.L.; Zhu, L.J.; Fang, Z.M.; Wu, N.; Du, M.X.; Jiang, M.M.; Wang, J.; Yao, Y.S. The network investigation on knowledge, attitude and practice about COVID-19 of the residents in Anhui Province. Zhonghua Yu Fang Yi Xue Za Zhi 2020, 54, 367-373.

27. Arrowood, R.B.; Cox, C.R.; Kersten, M.; Routledge, C.; Shelton, J.T.; Hood, R.W. Ebola salience, death-thought accessibility, and worldview defense: A terror management theory perspective. Death Stud. 2017, 41, 585-591. [CrossRef]

28. Menzies, R.E.; Menzies, R.G. Death anxiety in the time of COVID-19: Theoretical explanations and clinical implications. Cogn. Behav. Therap. 2020, 13, e19. [CrossRef]

29. Alawia, R.; Riad, A.; Kateeb, E. Risk perception and readiness of dental students to treat patients amid COVID-19: Implication for dental education. Oral Dis. 2020. [CrossRef] [PubMed]

30. Maričić, J.; Sučić, I.; Šakić, V. Risk perception related to (il)licit substance use and attitudes towards its' use and legalization-The role of age, gender and substance use. Drus. Istraz. 2013, 22, 579-599. [CrossRef]

31. Barakat, A.M.; Kasemy, Z.A. Preventive health behaviors during coronavirus disease 2019 pandemic based on health belief model among Egyptians. Middle East Curr. Psychiatry 2020, 27, 43. [CrossRef]

32. Hatabu, A.; Mao, X.; Zhou, Y.; Kawashita, N.; Wen, Z.; Ueda, M.; Takagi, T.; Tian, Y.S. Knowledge, attitudes, and practices toward COVID-19 among university students in Japan and associated factors: An online cross-sectional survey. PLOS ONE. 2020, 15, e0244350. [CrossRef]

33. Khasawneh, A.I.; Humeidan, A.A.; Alsulaiman, J.W.; Bloukh, S.; Ramadan, M.; Al-Shatanawi, T.N.; Awad, H.H.; Hijazi, W.Y.; AlKammash, K.R.; Obeidat, N. Medical students and COVID-19: Knowledge, attitudes, and precautionary measures. A descriptive study from Jordan. Front. Public Health 2020, 8, 253. [CrossRef] 